\title{
A review on wall-to-timber floor anchorages in URM buildings
}

\author{
Fabio Solarino, Daniel V. Oliveira \\ ISISE, Institute of Science and Innovation for Bio-Sustainability (IB-S), University of Minho, \\ Guimarães, Portugal
}

\section{Linda Giresini}

Department of Energy, Systems, Territory and Constructions Engineering (DESTEC), University of Pisa, Pisa, Italy

Contacting author: solarino.fabio@gmail.com

\begin{abstract}
Out of plane failure of unreinforced masonry walls is considered one of the most vulnerable seismic hazards in medium and high earthquake-prone regions. Efficient structural connections enable global equilibrated mechanisms, ensuring the "box-behavior". Timber floors are widely used as horizontal diaphragm in historical constructions, and their connection to the boundary walls is crucial to facilitate internal force redistribution and to restrain out of plane walls. Wall-to-floor anchorages are typical in existing historical buildings, and innovative solutions are proposed nowadays by engineers as strengthening devices. Unfortunately, they are often too invasive or unsustainable solutions, applied without reliable seismic design and evaluation through valid models.
\end{abstract}

This paper presents a literature review on the traditional and innovative wall-to-timber floor anchors used in unreinforced masonry buildings taking into account experimental works, analytical and numerical studies.

Keywords: wall-to-floor anchors; unreinforced masonry buildings; out of plane failure; state of the art.

\section{Introduction}

Out-of-plane (OOP) failure of unreinforced masonry (URM) walls is considered the first mode of failure and the last desirable (1), cause of catastrophic damages, as shown in past and recent seismic events (1931 M7.8 Hawke's Bay earthquake; 2009 M6.3 L'Aquila earthquake). Old masonry buildings were often built without the application of seismic concepts and practices, reacting poorly even under low and medium intensity earthquakes (2). The big variety on material types and geometry forces the analyst to study each problem as unique, considering (when possible) the experimental material properties. Without proper axial wall-to-floor connections the OOP walls (perpendicular to the direction of seismic forces) are highly vulnerable to OOP damages and failures (3). A sufficiently rigid diaphragm (relatively to structural walls) should also be connected to lateral in-plane (IP) walls (parallel to the direction of seismic forces) through 
proper shear connections, capable of distributing inertial forces to the seismic-resistant walls. The latter, together with general seismic details, provides the so-called "box-behavior" with the activation of global equilibrated mechanisms (4) (Figure 1).

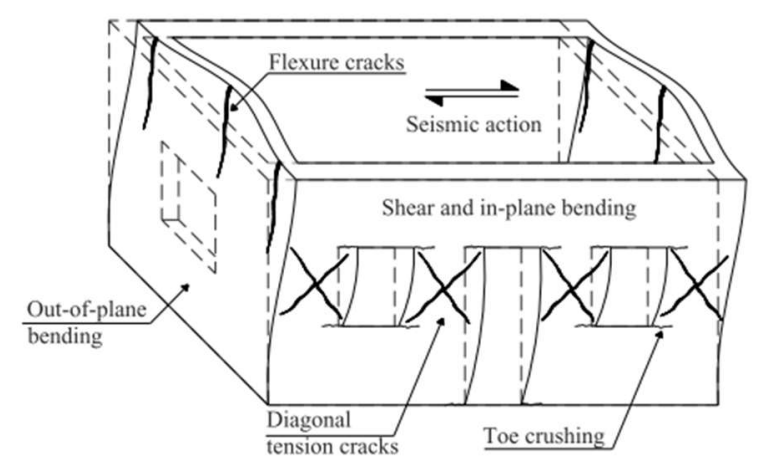

Figure 1. Global mechanisms typically observed in URM buildings (4)

Although the importance of seismic wall-to-floor anchors is well known with consensus among the research community, it is often a neglected topic in the assessment of existing buildings. Furthermore, researchers mainly focus on the global seismic behavior of the buildings, and strengthening solutions are suggested for the solely primary structural elements, such as walls and floors, or roofs $(5,6)$.

This paper presents a review on wall-to-timber floor anchors used to lower the seismic vulnerability of URM constructions. Both typical and innovative anchorages found in literature are shown in Section 2, while experimental and numerical approaches are summarized in Section 3 and 4 , respectively.

\section{Wall-to-timber floor anchors}

One of the most common and widely spread type of horizontal diaphragm in URM structures is timber floor, typically made up of timber beams and/or joists and wooden planks. Besides many examples where the timber ends are simply embedded into the width of the masonry wall or supported by stone corbels, relying only on the axial pull out (PO) capacity due to the friction generated from vertical static loads, different solutions can be found making use of metal anchorages, which link the external wall to the timber diaphragm. These devices (mainly in iron or steel) have the main function to provide a connection between the timber and the masonry through the use of plates, ties and welded, nailed or bolted connections. In relation with the large diversity of type they may transfer the axial or shear forces for static vertical forces or dynamic lateral loads.

Examples of iron wall anchors can be found in typical pre-1950s URM buildings in the Midwest region of the United States, where the cross or government plate is fixed to the anchor, simply nailed to the timber joist, providing a relatively weak connection with the masonry wall perpendicularly or in parallel $(7,8)$ (Figure 2 ).

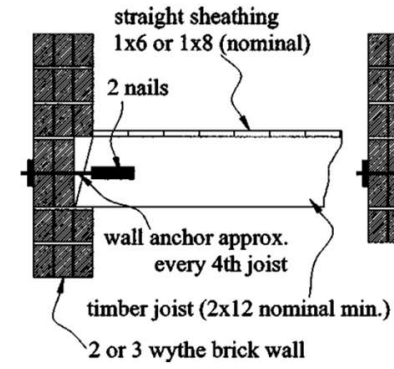

(a)

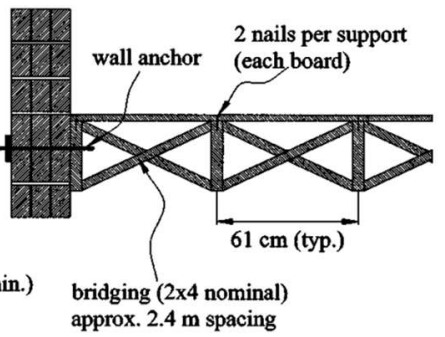

(b)
Figure 2. Iron anchors connecting outer walls to the perpendicular (a) or parallel joist (b) (8)

Similar bars with a typical fish-tail shape can be used to link the new timber headpiece (in place of the degrade one) to the rest of the beam and to the wall (9) (Figure 3a). The PO and shear seismic efficient of this connection can hardly be achieved.

Examples of more complex systems may be seen in Pombalino buildings in Lisbon, built after the 1755 earthquake as an attempt to create an anti-seismic masonry building. Timber vertical seismic frames (Pombalina) are built inside the perimeter of the masonry walls and the connections between the timber and the masonry are improved. Timber plates are placed above and below the joist header inside the masonry and fixed with nails (10), allowing a better distribution of the load to the wall and improving the axial and shear resistance. Typical connections include metal bars nailed to the timber and infixed into the masonry (Figure $3 b)$. Long bars $(1 \mathrm{~m})$ nailed diagonally to the joists 
and embedded under the timber planks can be anchored to the masonry wall, creating a more effective solutions (Figure 3c). Solutions shown by Cóias (9) include simple iron bar, squared, star shaped, or circular plates anchoring the bar to the exterior face of the masonry wall (Figure 3d) increasing the PO resistance of the connection, as relying also on the compressive strength of the masonry.

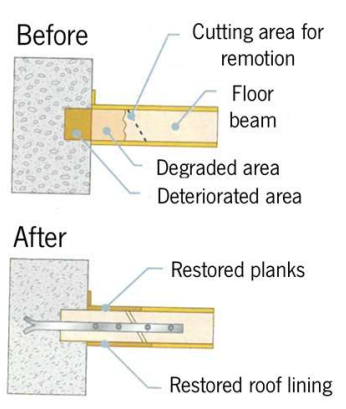

(a)

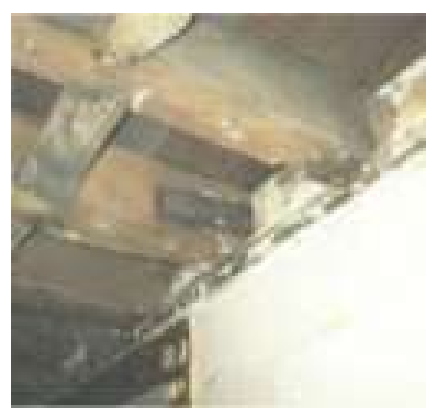

(b)

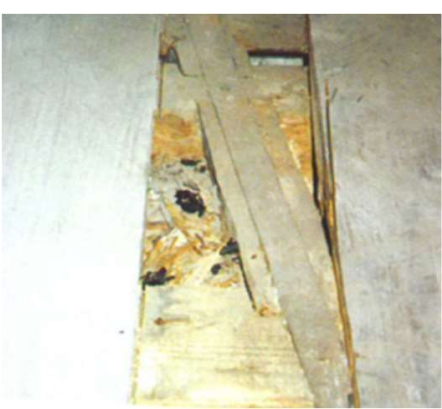

(c)
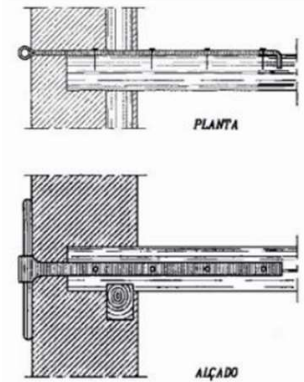

(d)

Figure 3. Timber to masonry anchors $(9,10)$ : (a) degrade timber joist headpiece replacement; (b) iron strap; (c) diagonal bar embedded into transversal joists; (d) roof-to-wall connection

A strengthening solution proposed by Tomaževič (4) comprises a double steel anchor symmetrically bolted to the joist to avoid eccentricity (Figure 4).

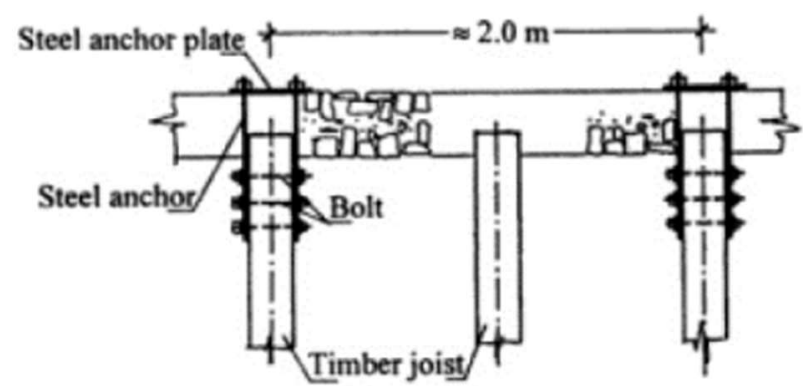

Figure 4. Double bolted anchor system (4)

Bolted connections increase the shear resistance and improve the PO behavior of the solution. Further retrofitting solutions adopted after New Zealand 1931 Hawke's Bay earthquake are described by Blaikie and Spurr (11) and include steel anchors connected to a steel angle plate bolted to the joist. The anchorage to the masonry is provided by the use of steel bearing plates (Figure 5).

Innovative solutions studied by Moreira (12) comprises hinges at both ends of the steel tie allowing an easier manufacturing of the tie itself fixed diagonally on proper reinforced steel angles directly from the top of the floor (Figure 6).

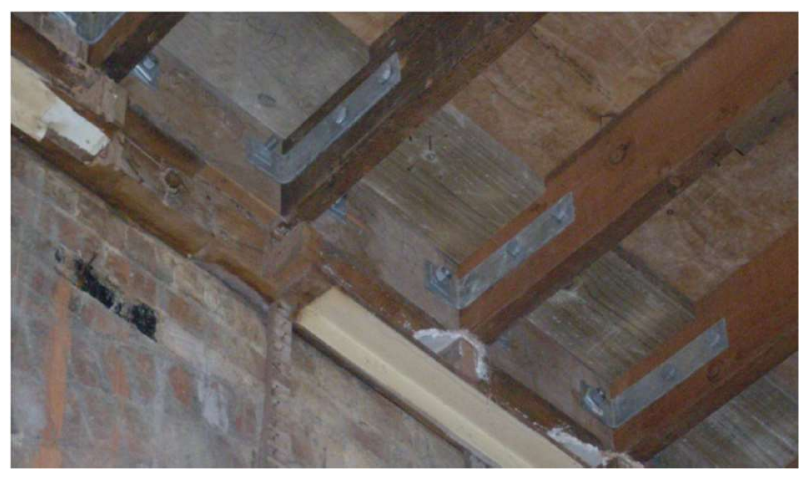

Figure 5. Wall to floor strengthening bolted solutions using steel rods bolted to steel angles

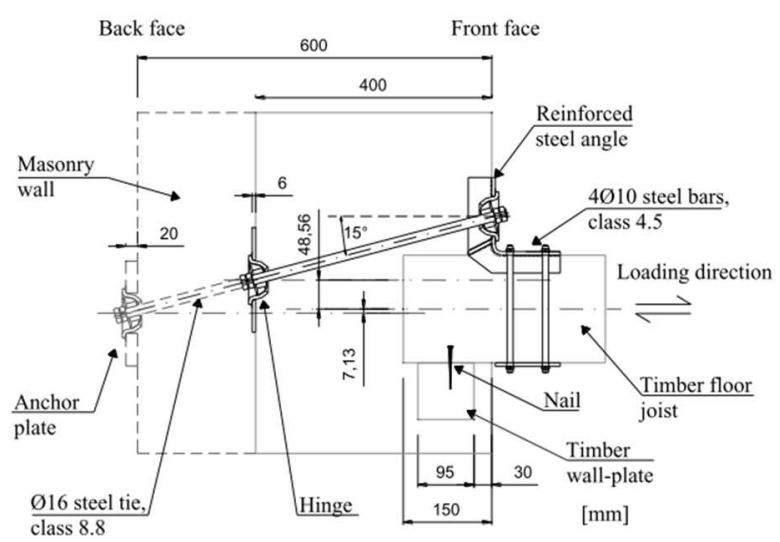

Figure 6. Innovative bolted solution studied by Moreira (12) 
The use of injected anchors also become an interesting solution thanks to the introduction of resins or epoxy-based mortars and allows for a minimal interfere with the aspect of the original façade. An example of such solution is proposed by Cóias (9) where the grout injection controls the bond behavior between the steel tie and the surrounded masonry (Figure 7). The connection to the timber joist is usually ensured by a bolted steel angle.

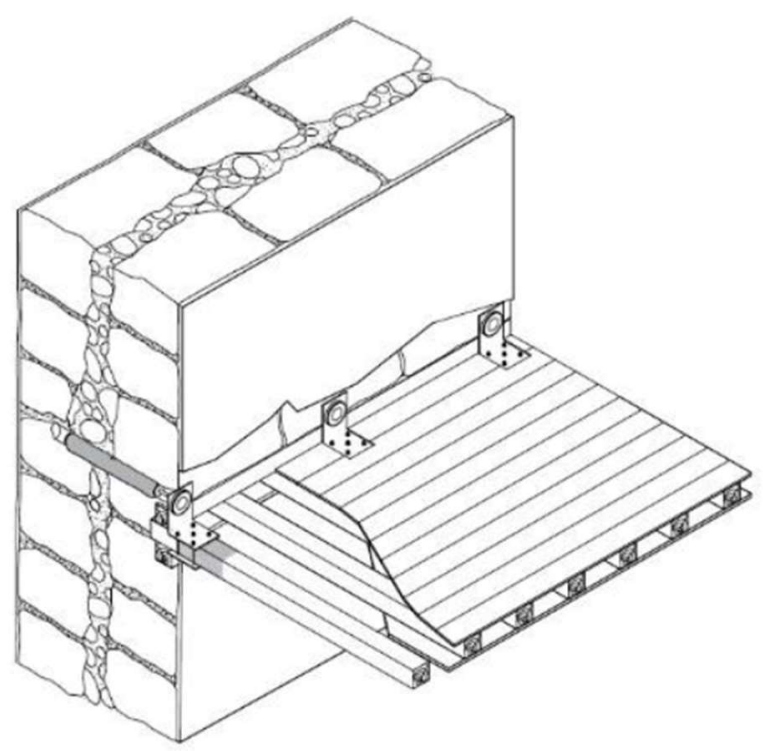

Figure 7. Strengthening solution proposed for Pombalino buildings (9)

The arrival of reinforced concrete (RC) let to the almost totally abandonment of masonry as primary structural material. Moreover, newly URM building are provided with RC bond beams at floor levels allowing the connection between the slab and the wall, also offering higher diaphragm action, usually very poor in existing URM buildings with flexible diaphragm (4). Even if it was typical to replace light timber floors or roofs with heavy RC slabs, this solution should be avoided because of increase in dangerous inertial seismic forces. Hsiao and Tezcan (13) propose a chord strengthening solution on the bases of American standard FEMA (14) avoiding the damage of the original figure of a historic building. The solution is shown in Figure 8 and aims at reinforcing the IP and OOP connections between the wood diaphragms and the URM bearing walls and increase the flexural capacity of the diaphragms reinforcing the chord element through the use of a continuum steel angle along the edges of the timber diaphragm connected to the masonry using anchor bolts or alternate injection anchorages in order to preserve the original figure of the external façade.

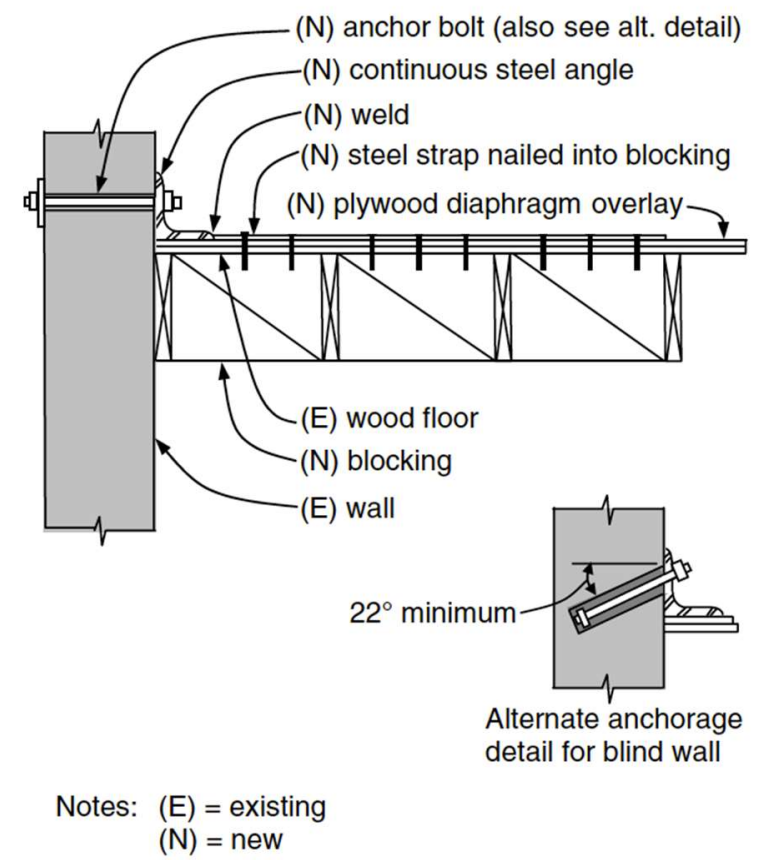

Figure 8. Chord strengthening connection using continuous steel angles (13)

\section{Experimental studies}

Experimental laboratory or in-situ test are extremely important to understand the influence of the strengthening connections over the whole building and to characterize the mechanical behavior of the existing and strengthened connection. A global understanding of the efficiency of the connections may be achieved through shaking table tests on real- or reducedscale specimens. Such tests are usually performed on global building scale (15-17) or local wall scale $(18,19)$ but only few have the aim to study the effectiveness of the wall-to-floor connections and strengthening solutions are suggested for the solely primary elements $(6,20)$.

The static and dynamic characterization of the connections may be achieved through detail-scale PO or shear tests aiming at the development of force-displacement curves, necessary for 
numerical model validation. Typical diaphragm-tobrick wall connections are reproduced by Lin and LaFave (7) and studied through static monotonic, as well as dynamic cyclic tests, considering the contribution of friction and strap anchor nails (Figure 9a). Results suggests that the dynamic response is more brittle if compared to the static ones (Figure 9b).

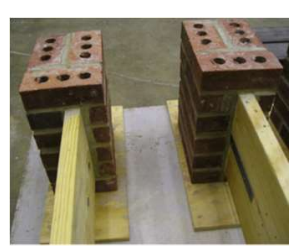

(a)

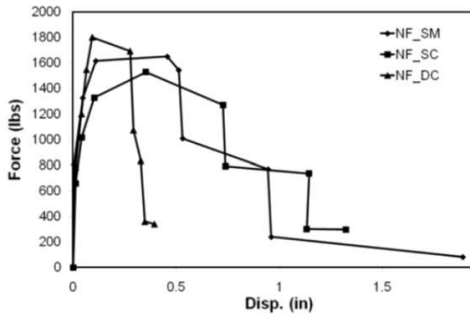

(b)
Figure 9. Experimental campaign on typical walldiaphragm connections (7): (a) test specimens; (b) comparison between static monotonic (SM), quasistatic cyclic (SC) and dynamic cyclic (DC) average curves, considering the contribution of friction and nailed straps (NF)

Six existing steel anchors extracted from damaged URM building after 2010 M7.1 Christchurch earthquake are studied by Campbell et al. (21) through axial destructive tests. Based on such relatively small number of samples tests and considering the 2010/11 Canterbury earthquake sequence damage observations, the authors suggest seven plausible failure modes of the connection and values of ultimate tensile strength are recommended, even if further testing increasing the dataset are necessary (Figure 10).

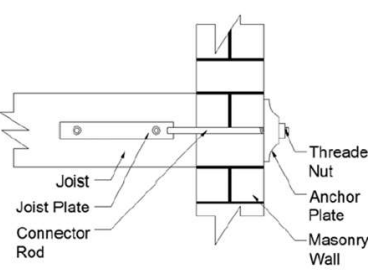

(a)

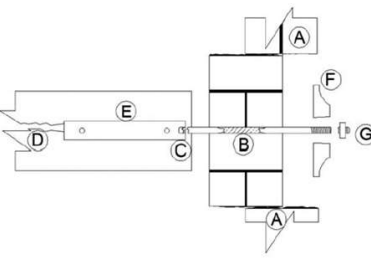

(b)
Figure 10. Typical New Zealand anchors: (a) connection assembly; (b) location of failure modes
Jacks and Beattie (22) investigate the PO static and dynamic behavior of through-bolt and epoxied-in anchors in URM walls. No PO failure is found to occur on bolted anchors even under high load levels, while the formation of cracks distributed across the full width of the test panel is obtained for epoxied-in anchors. A set of design equations is suggested by Karim et al. (23) to assess the timber joist bolted connection based on experimental studies focused on the failure mechanism. The minimum strength value will govern the capacity of the whole connection. Typical wall-to-floor connections of late $19^{\text {th }}$ century in Lisbon are experimentally studied by Moreira (12) in both unstrengthened and strengthened configuration through quasi-static monotonic and cyclic PO tests. The strengthened connection (Figure 6) relies on steel tie-rods anchored to the wall with anchor plates. Steel angles are placed inside to link the steel ties to the timber joist using bolted connections. Hinges are places at both ends of the ties reducing the bending force induced by the timber beam to the anchor, diagonally infixed into the masonry. The tensile capacity of the strengthened connections results to be approximately 19 times greater than the one of the unstrengthened ones (timber joist simply nailed to the lower timber plate and embedded into the masonry) and is characterized by the yielding of the steel angle, crushing and shearing of the timber (Figure 11). A retrofit design proposal is recommended, and future works suggested to establish hysteretic rules useful to implement the connection as an element in numerical models.

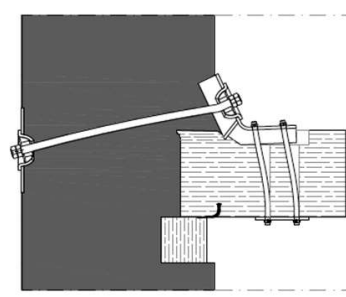

(a)

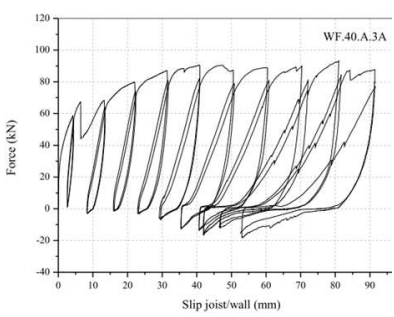

(b)
Figure 11. Cyclic test on innovative strengthened connection (12): (a) observed damage and failure mode; (b) cyclic curves 
The pull-out capacity (POC) of grouted anchors is investigated by Ismail (24) as possible retrofitting solution in wall-to-diaphragm connections (Figure 12). The influence of embedment length, installation quality, anchor location, condition of masonry and condition of substrate materials on anchor performance are investigated. the highest probability of failure during an earthquake is associated to the failure of anchor-diaphragm connection and thus limits the achievable POC of the wall-diaphragm anchorage system. However, this type of failure is observed to be reasonably ductile.

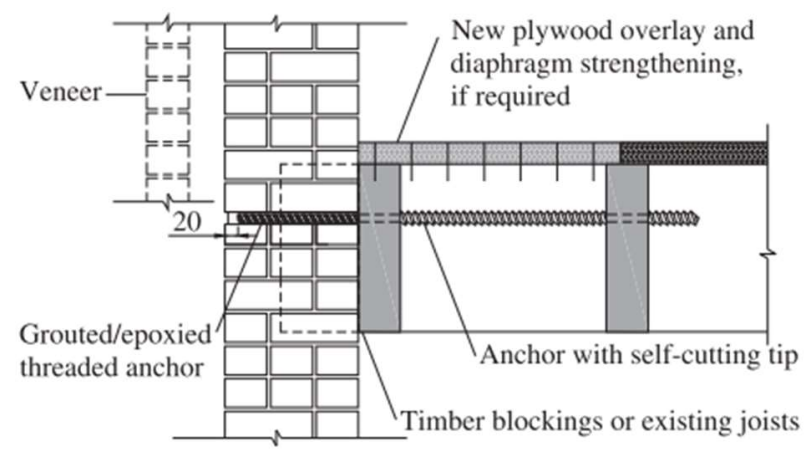

Figure 12. Possible strengthening set up suggested by Ismail (24) based on grouted threaded anchor

Further studies on adhesive anchor connections between brick URM walls and floor diaphragm are undertaken by Dizhur et al. (25) considering almost 400 specimens. The authors focus on the role of the main parameters on the POC of the whole connection. Cementitious grout is a suitable anchor adhesive and the optimum size of the rod diameter is found to be $16 \mathrm{~mm}$. Low overburden weight negatively influences the POC, while an accurate installation process increases it significantly. No conical masonry failure surface is observed in any of the tests, and a design equation of the POC of adhesive anchors is proposed.

Recently, Dizhur et al. (26) undertake experimental tests on two different types of anchorages between the masonry anchor and the timber diaphragm: (i) metal connector bolted to the joist through a joist plate (Figure 13a), and (ii) connections making use of timber blocking (vertical and horizontal timber elements interconnected between the joists bolted to the masonry anchor) (Figure 13c). Results demonstrate how the joist plate anchor connection mainly fail in splitting of the timber joist (Figure 13b), while the highest performance is achieved positioning the timber blocking horizontally. Timber bearing failure is observed if small washers are used (Figure 13d).

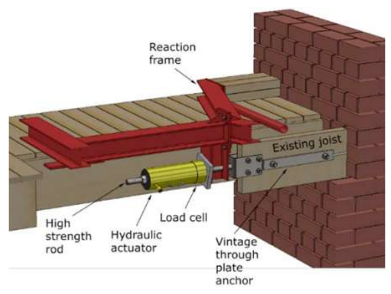

(a)

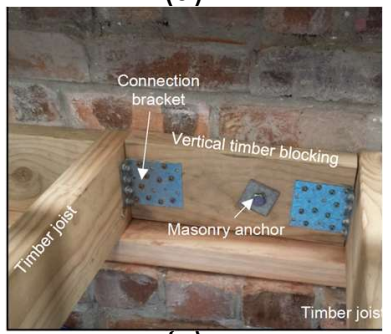

(c)

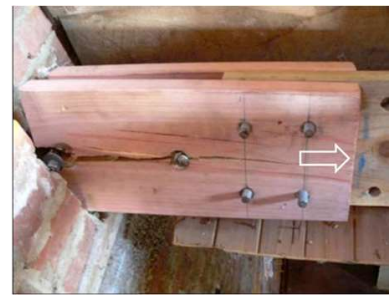

(b)

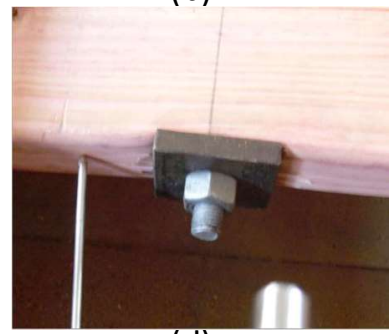

(d)
Figure 13. Experimental campaign on wall-todiaphragm specimens (26): (a) schematic diagram of joist plate connection set up; (b) row shear failure of timber joists; (c) timber blocking system; (d) timber bearing failure of washer

\section{Numerical/analytical approaches}

A considerable number of modelling techniques are available for the seismic analysis and assessment of URM constructions in a building scale $(27,28)$ and local scale (i.e. OOP mechanism) $(29,30)$, but only few include the behavior of the connections between vertical and horizontal members interfaces $(19,31)$. Moreover, the authors often consider the connection assuming simplified hypothesis (i.e. perfect hinges or linear elastic springs), neglecting the cyclic nonlinear behavior, typical for many types of links and reducing the number of the degrees of complexity of the dynamic problem. The most common modelling techniques comprise rigid block approaches, numerical finite elements models (FEM), and distinct (or discrete) elements models (DEM). For rigid block approaches, the capacity can be computed through static or kinematic analysis. Static pushover and dynamic analysis with timestep integration under artificial or real 
accelerograms are, on the other hand, common tools when FEM or DEM techniques are adopted $(32,33)$. It must be noted that force based approaches (FBA) are preferred by practitioners as simple and direct methods, in spite of high conservative results, while displacement based approaches (DBA) appears to be adequate for cracked walls falling into the nonlinear range (29).

The influence of floor on the seismic response of URM structures is investigated in the work of TenaColunga and Abrams (34) through discrete dynamic models, based on linear masonry behavior and flexible and linear diaphragms modelled as elastic springs (Figure 14). Results show how diaphragm accelerations can increase with the flexibility of the diaphragm. Moreover, torsional effects are reduced considerably as diaphragm flexibility increases.

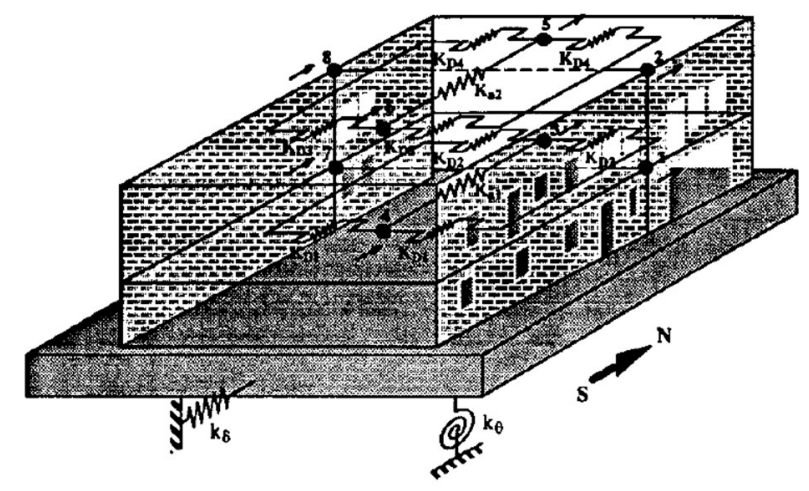

Figure 14. Discrete dynamic models of URM buildings by Tena-Colunga and Abrams (34).

An unconventional procedure for the simulation of the OOP dynamic behavior of URM buildings, considering the stiffness of the roof, is performed by Costa (35), where the local mechanisms is modelled as kinematic chains of masonry portions (normally assumed as infinitely rigid bodies) whose nonlinear behavior is concentrated at the contact regions (Figure 15a). Springs simulate the IP stiffness of the horizontal diaphragm and lumped mass located at the ridge and top spreader beams represent the roof mass. Experimental behavior of a full scale URM building tested at EUCENTRE (15) is simulated with sufficient accuracy through this numerical approach, where elastic springs are placed at the top of each roof pitch. The predefinition of the formed local mechanisms sets the limits and the drawback of the method, but the approach is a quick and simple method relying only on the assumption of few parameters.

The software TREMURI (36) is used as an equivalent frame approach where it is possible to include nonlinear beam elements to account for the presence of RC ring beams and wall-todiaphragm connections at floor level. Pushover curves obtained using such approach are compared to the experimental resistance curve developed by Senaldi et al. (16), showing well similarities (Figure 15b).

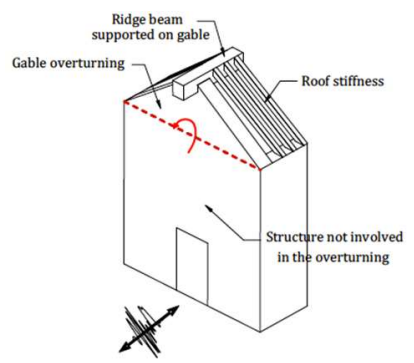

(a)

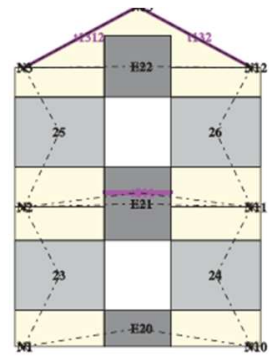

(b)
Figure 15. Macro-element models of URM buildings: (a) multi-body dynamics-based approach (35); (b) equivalent frame approach developed in TREMURI (16).

Local scale approaches are essential in the assessment of local mechanisms (i.e. OOP overturning of partial walls) frequently activated in URM buildings stroke by seismic events of high or low intensities.

Starting from the work of Giuffrè (37) on 1994, rigid body limit analysis reveals to be a powerful tool for the seismic safety check of local mechanisms, where it is possible to account for strengthening techniques such as insertion of tie-rods, rigid diaphragm, anchors, etc.. The maximum horizontal load multiplier can be compared to the maximum expected PGA evaluated from the response spectrum for bilinear non-dissipative model. The assumption of the local mechanism is necessary for such approach to be used. D'Ayala and Speranza (38) provide several load factor formulation for each overturning mechanisms (Figure 16) implemented in the FaMIVE (Failure Mechanism Identification and Vulnerability Evaluation) procedure for online evaluation of a façade or building seismic vulnerability. Such procedure can handle a large number of buildings in order to 
perform statistical analysis, taking into account the presence or not of strengthening devices.

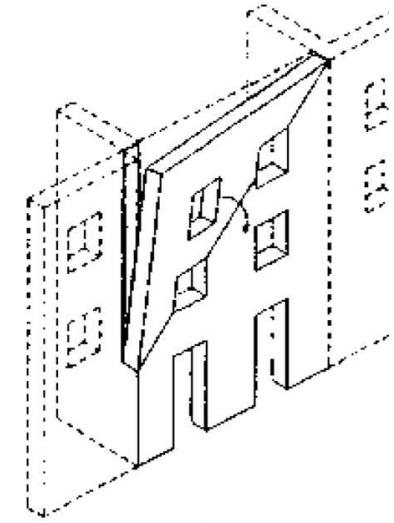

(a)

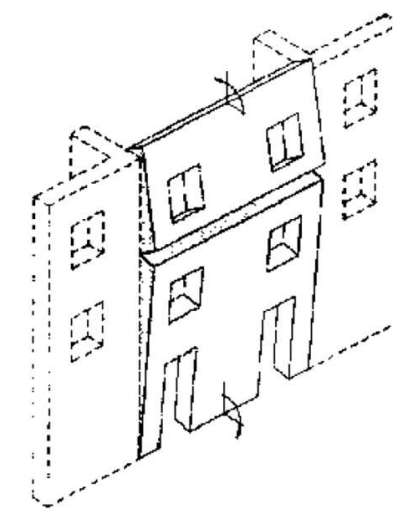

(b)
Figure 16. Mechanisms for OOP failures studied by D'Ayala and Speranza (38)

When a monolithic model of the masonry involved in the mechanism can be reasonably assumed, rocking dynamic analysis is a reliable alternative to the kinematic one. Based on pioneering work of Housner (39), the rocking motion of a simple rigid prismatic block about two corners $\mathrm{O}$ and $\mathrm{O}^{\prime}$ (Figure 17a) may be analysed under free vibrations, constant or sinusoidal accelerations and real or artificial earthquake motion. The contribution of implementing the equation of motion on a computer program is given by Aslam (40), while Giresini $(41,42)$ introduces the influence of possible thrusts and horizontal restraints to simulate tie rods, flexible diaphragm or transverse walls (Figure $17 \mathrm{~b})$. The method is a promising approach, but does not find yet application on standard codes, even if comparisons with experimental results demonstrate its accuracy. MDOF systems may be a more realistic representation of OOP rocking mechanisms in URM walls. To account for such more complex systems, different authors $(43,44)$ derive the equation of motion for 2 or 3DOF models, but only Landi et al. (31) the influence of flexible diaphragms on OOP bending of the URM façades. The diaphragm is simulated through the introduction of a spring on top (Figure 17c) and the model is calibrated on experimental tests. Results demonstrates the high sensitivity of the model to the stiffness of the spring.

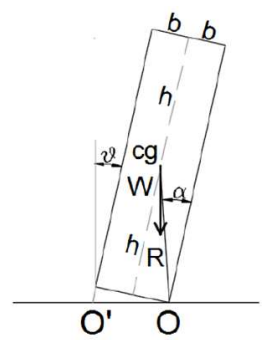

(a)

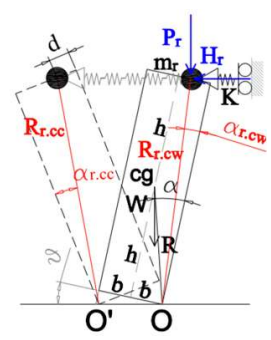

(b)

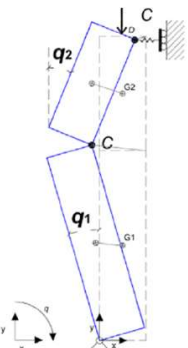

(c)
Figure 17. Dynamic stability analysis of rigid rocking blocks: (a) Housner free block model (39); (b) restrained rocking block (41); (c) 2DOF model (31)

\section{Conclusions}

This paper presents a literature review on wall-totimber floor anchorages in URM buildings, considering the existing traditional connections and the main strengthening solutions in experimental and numerical frameworks.

Despite it is common the use of anchoring systems in existing URM buildings as low-invasive antiseismic devices, many engineers make use of inappropriate solutions that may modify the original aesthetic and structural concept of the construction. Moreover, invasive material such as $\mathrm{RC}$ are often used in replacement of the original ones because of their availability. Strengthening the connections using compatible materials (such as timber) may, in turn, be a more sustainable alternative for the safety restoration of the building, making use of innovative materials, such as steel or new resins only locally and maintaining its original external and internal aspect.

Accounting for wall-to-floor connections in the analysis of URM appears to be crucial for the evaluation of existing and reinforced buildings. Experimental characterization of the single connection type is challenging but necessary for a reliable model to be performed. A large set of parameters may be investigated through parametric numerical analyses on calibrated model.

The linear and non-linear kinematic analysis seems the most used as simple and powerful tool for the evaluation of local mechanisms. Furthermore, the rocking approach considers the evolution of motion during time and dissipation properties at 
the plastic hinge around which the masonry wall rotates are not neglected. Such procedures are based on hypothesis of monolithic blocks, not always true for masonry walls or façades. Even if FEM analysis is the most used among practitioners as quick and simple, it is based on uncertain mechanical characteristics of masonry elements, setting the limits of the method.

\section{Acknowledgements}

This work was partly financed by FEDER funds through the Competitively Factors Operational Programme - COMPETE and by national funds through FCT - Foundation for Science and Technology within the scope of project POCI-010145-FEDER-007633. The support to the $1^{\text {st }}$ author through grant SFRH/BD/131652/2017 is also acknowledged.

\section{References}

[1] Brignola A, Podestà S, Pampanin S. In-plane stiffness of wooden floor. 2008 NZSEE Conference, Paper 49. [Online] 2008;(49): 1$19 . \quad$ Available from: http://ir.canterbury.ac.nz/handle/10092/26 57\%5Cnhttp://hdl.handle.net/10092/2657

[2] Menon A, Magenes G. Out-of-plane seismic response of unreinforced masonry: definition of seismic input. Fondazione EUCENTRE (ed.) Research Report ROSE - 2008/04. Pavia: IUSS Press; 2008.

[3] Lang K, Bachmann $H$. On the seismic vulnerability of existing unreinforced masonry buildings. Journal of Earthquake Engineering. [Online] 2003;7(3): 407-426. Available from: doi:10.1080/13632460309350456

[4] Tomaževič M. Earthquake-Resistant Design of Masonry Buildings. [Online] A. S. Elnashai \& P. J. Dowling Eds. (ed.) London, UK: Imperial College Press; 1999. Available from: doi:10.1142/9781848160835

[5] Giuffrè A. A Mechanical Model for Statics and Dynamics of Historical Masonry Buildings. In: Petrini V (ed.) Protection of the Architectural Heritage Against Earthquakes. [Online] Vienna; 1996. p. 71-152. Available from: doi:10.1007/978-3-7091-2656-1_4
[6] Ismail N, Ingham JM. In-plane and out-ofplane testing of unreinforced masonry walls strengthened using polymer textile reinforced mortar. Engineering Structures. [Online] 2016;118: 167-177. Available from: doi:10.1016/j.engstruct.2016.03.041

[7] Lin TJ, LaFave JM. Experimental structural behavior of wall-diaphragm connections for older masonry buildings. Construction and Building Materials. [Online] 2012;26(1): 180-189. Available from: doi:10.1016/j.conbuildmat.2011.06.008

[8] Peralta DF, Bracci JM, Hueste MBD. Seismic behavior of wood diaphragms in pre-1950s unreinforced masonry buildings. Journal of Structural Engineering. [Online] 2004;130(12): 2040-2050. Available from: doi:10.1061/(ASCE)07339445(2004)130:12(2040)

[9] Cóias V. Reabilitação Estrutural de Edifícios Antigos - Alvenaria, Madeira - Técnicas pouco intrusivas. Lisbon, Portugal: Ed. Argumentum \& Gecorpa (In Portuguese); 2007.

[10] Appleton J. Reabilitação de Edifícios Antigos - Patologias e Tecnologias de Intervenção. Orion (ed.) Amadora; 2003.

[11] Blaikie EL, Spurr DD. Earthquake Vulnerability of Existing Unreinforced Masonry Buildings. Works Consultancy Services (ed.) Wellington, NZ; 1992.

[12] Moreira SMT. Seismic retrofit of masonry-totimber connections in historical constructions. Universidade do Minho; 2015.

[13] Hsiao KJ, Tezcan J. Seismic Retrofitting for Chord Reinforcement for Unreinforced Masonry Historic Buildings with Flexible Diaphragms. American Society of Civil Engineers. [Online] 2012;17(August). Available from: doi:10.1061/(ASCE)SC

[14] FEMA. NEHRP Handbook of Techniques for the Seismic Rehabilitation of Existing Buildings (FEMA-172). Building Seismic Safety Council for FEMA, Washington, D.C. [Online] 1992;(June). Available from: doi:10.1061/9780784408841

[15] Magenes G, Penna A, Senaldi IE, Rota M, Galasco A. Shaking table test of a strengthened full-scale stone masonry building with flexible diaphragms. 
International Journal of Architectural Heritage. [Online] 2014;8(3): 349-375. Available from: doi:10.1080/15583058.2013.826299

[16] Senaldi IE, Magenes G, Penna A, Galasco A, Rota $M$. The effect of stiffened floor and roof diaphragms on the experimental seismic response of a full-scale unreinforced stone masonry building. Journal of Earthquake Engineering. [Online] 2014;18(3): 407-443. Available from: doi:10.1080/13632469.2013.876946

[17] Vintzileou E, Mouzakis C, Adami CE, Karapitta L. Seismic behavior of three-leaf stone masonry buildings before and after interventions: Shaking table tests on a twostorey masonry model. Bulletin of Earthquake Engineering. [Online] 2015;13(10): 3107-3133. Available from: doi:10.1007/s10518-015-9746-x

[18] Dazio A. The effect of the boundary conditions on the out-of-plane behaviour of unreinforced masonry walls. Proceedings of the 14th World Conference on Earthquake Engineering. Beijing, China; 2008.

[19] Simsir CC, Aschheim MA, Abrams DP. Out-ofplane dynamic response of unreinforced bearing walls attached to flexible diaphragms. Proceedings of 13th World Conference on Earthquake Engineering. 2004. p. 15.

[20] Scotta R, Trutalli D, Marchi L, Pozza L. Seismic performance of URM buildings with in-plane non-stiffened and stiffened timber floors. Engineering Structures. [Online] 2018;167: 683-694. Available from: doi:10.1016/j.engstruct.2018.02.060

[21] Campbell J, Dizhur D, Hodgson M, Fergusson $G$, Ingham JM. Test results for extracted wallto-diaphragm anchors from Christchurch unreinforced masonry buildings. SESOC Journal. 2012;25(1): 57-67.

[22] Jacks DH, Beattie GJ. Dynamic Testing of Seismic Anchors in Unreinforced Brick Masonry Walls. Lower Hutt, New Zealand: Works Consultancy Services; 1990.

[23] Abdul Karim AR, Quenneville P, Sa'don NM, Ingham J. Assessment guidelines of walldiaphragm connections for masonry buildings. 7th International Structural
Engineering and Construction Conference. [Online] 2013. p. 1019-1024. Available from: doi:10.3850/978-981-07-5354-2 St-136-427

[24] Ismail N. Performance of Wall to Diaphragm Anchors for Use in Seismic Upgrade of Heritage Masonry Buildings. International Journal of Architectural Heritage. [Online] Taylor \& Francis; 2016;10(7): 829-840. Available from: doi:10.1080/15583058.2016.1144115

[25] Dizhur D, Schultz A, Ingham JM. Pull-out behavior of adhesive connections in unreinforced masonry walls. Earthquake Spectra. [Online] 2016;32(4): 2357-2375. Available

from: doi:10.1193/011115EQS006M

[26] Dizhur D, Giaretton M, Ingham JM. URM wall-to-diaphragm and timber joist connection testing. 10th International Masonry Conference - IMC. 2018.

[27] de Felice G, De Santis S, Lourenço PB, Mendes N. Methods and Challenges for the Seismic Assessment of Historic Masonry Structures. International Journal of Architectural Heritage. [Online] Taylor \& Francis; 2017;11(1): 143-160. Available from: doi:10.1080/15583058.2016.1238976

[28] Penna A. Seismic assessment of existing and strengthened stone-masonry buildings: Critical issues and possible strategies. Bulletin of Earthquake Engineering. [Online] 2015;13(4): 1051-1071. Available from: doi:10.1007/s10518-014-9659-0

[29] Sorrentino L, D'Ayala D, de Felice G, Griffith $M C$, Lagomarsino S, Magenes G. Review of Out-of-Plane Seismic Assessment Techniques Applied To Existing Masonry Buildings. International Journal of Architectural Heritage. [Online] Taylor \& Francis; 2017;11(1): 2-21. Available from: doi:10.1080/15583058.2016.1237586

[30] Ferreira TM, Costa AA, Costa A. Analysis of the Out-Of-Plane Seismic Behavior of Unreinforced Masonry: A Literature Review. International Journal of Architectural Heritage. [Online] Taylor \& Francis; 2015;9(8): 949-972. Available from: doi:10.1080/15583058.2014.885996

[31] Landi L, Gabellieri R, Diotallevi PP. A model for the out-of-plane dynamic analysis of 
unreinforced masonry walls in buildings with flexible diaphragms. Soil Dynamics and Earthquake Engineering. [Online] Elsevier; 2015;79: 211-222. Available from: doi:10.1016/j.soildyn.2015.09.013

[32] Pantò B, Giresini L, Sassu M, Caliò I. Nonlinear modeling of masonry churches through a discrete macro-element approach. Earthquake and Structures. [Online] 2017; Available from: doi:10.12989/eas.2017.12.2.223

[33] Lemos J V. Discrete element modeling of masonry structures. International Journal of Architectural Heritage. [Online] 2007; Available from: doi:10.1080/15583050601176868

[34] Tena-Colunga A, Abrams D. Seismic behavior of structures with flexible diaphragms. Journal of Structural Engineering. [Online] 1996;122(4): 439-445. Available from: doi:10.1061/(ASCE)07339445(1996)122:4(439)

[35] Costa AA. Seismic Assessment of the Out of Plane Performance of Traditional Stone Masonry Walls. 2012;(March 2012): 233.

[36] Lagomarsino S, Penna A, Galasco A, Cattari S. TREMURI program: An equivalent frame model for the nonlinear seismic analysis of masonry buildings. Engineering Structures. [Online] 2013; Available from: doi:10.1016/j.engstruct.2013.08.002

[37] Giuffrè A. Seismic safety and strengthening of historical buildings and urban fabrics. Earthquake Engineering, Tenth World Conference. Balkema, Rotterdam.; 1994. p. 6583-96.

[38] D’Ayala D, Speranza E. Definition of Collapse Mechanisms and Seismic Vulnerability of Historic Masonry Buildings. Earthquake Spectra. [Online] 2003;19(3): 479-509. Available from: doi:10.1193/1.1599896

[39] Housner GW. The behavior of inverted pendulum structures during earthquakes. Bulletin of the Seismological Society of America. [Online] 1963;53(2): 403-417. Available from: doi:10.1017/СBO9781107415324.004

[40] Aslam M, Godden WG, Scalise DT. Earthquake Rocking Response of Rigid Bodies. Journal of the Structural Division.
1980;106(2): 377-392.

[41] Giresini L, Fragiacomo M, Sassu M. Rocking analysis of masonry walls interacting with roofs. Engineering Structures. Elsevier Ltd; 2016;116: 107-120.

[42] Giresini L, Casapulla C, Denysiuk R, Matos J, Sassu M. Fragility curves for free and restrained rocking masonry façades in onesided motion. Engineering Structures. [Online] Elsevier; 2018;164(February): 195213. Available from: doi:10.1016/j.engstruct.2018.03.003

[43] Psycharis IN. Dynamic behaviour of rocking two-block assemblies. Earthquake Engineering \& Structural Dynamics. [Online] 1990;19(4): 555-575. Available from: doi:10.1002/eqe.4290190407

[44] Kounadis AN, Papadopoulos GJ. On the rocking instability of a three-rigid block system under ground excitation. Archive of Applied Mechanics. [Online] 2016;86(5): 957-977. Available from: doi:10.1007/s00419-015-1073-9 